\title{
Evaluation of the Clinical Effects of Ombitasvir/Paritaprevir/ Ritonavir Regimen in the Treatment of Chronic HCV Patients in CKD Versus ESRD Patients in Assiut University Hospital
}

\author{
SHALA Kh. EL-SHERIF, M.D.*; ESSAM M. ABD EL-AZIZ, M.D.* and MONA ABD EL-LATIF ALI, M.Sc.** \\ The Departments of Internal Medecine \& Endocrinology* and Npherology**, Faculty of Medicine, Assiut University, Egypt
}

\begin{abstract}
Background: Assesing curability of Ombitasvir/Paritaprevir/Ritonavir regimen in chronic HCV infected patients in those with ESRD and CKD.

Aim of Work: To asses, curability of Ombitasvir/Paritaprevir/Ritonavir in chronic HCV infected patients in those with ESRD vs CKD, and assess duration of sustained viral therapy in Assiut Hospital University.

Patients and Methods: It is a prospective study which included 40 patients at Hemodialysis unit and Internal Medicine department in Assiut University Hospitals though one year. Then Patient will be divided into 2 group: Group I: 20 ESRD Patients on regular heamodialysis $>6$ months with chronic HCV infection. Group II: 20 CKD Patients with chronic HCV infection did not start dialysis.

Results: (SVR) was assessed at 12 and 24 weeks posttherapy. All patients in each group achieved SVR at 12 weeks but at 24 week. $85 \%$ of patients with ESRD achieved SVR while all those with CKD achieved SVR.

Conclusion: We found that the curability of Ombitasvir /Paritaprevir/Ritonavir plus Ribavirin has SVR12 about 100\% and SVR24 100\% in CKD patients, 85\% in ESRD patients. With less incidence of anemia with that regimen as only $10 \%$ patients need blood transfusion. With high tolerability and less side effects with no occurrence of discontinuation of treatment.
\end{abstract}

Key Words: Treatment of HCV in renal impairment.

\section{Introduction}

HEPATITIS C virus (HCV) is a leading cause of liver disease worldwide, as 130-170 million individuals are chronically infected and 350,000 patients die every year from HCV infection. The HCV prevalence varies widely among countries being highest in several African and Eastern Mediterranean countries. Public health authorities

Correspondence to: Dr. Mona Abd El-Latif Ali, The Department of Npherology, Faculty of Medicine, Assiut University, Egypt should recognise the importance of $\mathrm{HCV}$ and make resources available for the implementation of effective primary prevention, screening, and management policies [7]. Hepatitis $\mathrm{C}$ virus (HCV) infection is a major health problem in patients with end-stage renal disease (ESRD). The incidence of acute $\mathrm{HCV}$ infection during maintenance dialysis is much higher than that in the general population because of the risk of nosocomial transmission. Following acute HCV infection, most patients develop chronic $\mathrm{HCV}$ infection, and a significant proportion develops chronic hepatitis, cirrhosis, and even hepatocellular carcinoma. Overall, chronic hepatitis $\mathrm{C}$ patients on hemodialysis bear an increased risk of liver-related morbidity and mortality during [5]. The prevalence of anti-hepatitis $\mathrm{C}$ virus $\mathrm{Ab}$ (anti-HCV) positivity among dialysis patients varies across countries, ranging from 3 to $75 \%$; unfortunately, Egypt is considered one of the countries with the highest prevalence despite the existence of guidelines for a comprehensive infection control program [13].

\section{Patients and Methods}

Prospective, randomized, double blind, comparative study was conducted at Heamodialysis unit and Internal Medicine department in Assiut University Hospitals Assiut University hospital after international review board (IRB) approval from the Medical Ethic Committee, Faculty of Medicine, Assiut University, Assiut, Egypt. Trial registration was prospectively undertaken in clinical trial. Gov (ID: NCT03341988) on one year between November 2016 and November 2017.

Aim of the work: To assess curability of (Ombitasvir, Paritaprevir, and Ritonavir) with or without ribavirin in chronic $\mathrm{HCV}$ infected patients in those 
with ESRD versus CKD patients. Also, to assess duration of sustained viral response, relapse or failure of therapy in ESRD versus CKD patients in Assiut University Hospital.

The dose of the regimenis one tablet containing Ombitasvir (12.5mg), Paritaprevir (75mg), and Ritonavir (50mg) twice daily with Ribavirin (RBV): weight-based and divided bid $(1000 \mathrm{mg} /$ day if $<75 \mathrm{~kg}$ or $1200 \mathrm{mg} /$ day if $\geq 75 \mathrm{~kg}$. Our study will be conducted on fourty patients in Assiut University Hospitals. Then the Patients will be subdivided into 2 groups: Group I: 20 ESRD Patients on regular heamodialysis $>6$ months with chronic hepatitis $\mathrm{C}$ infection. Group II: 20 CKD Patients with chronic hepatitis $\mathrm{C}$ virus infection did not start dialysis.

Inclusion criteria: Age 18-60ys old, CKD patients with chronic $\mathrm{HCV}$ who did not start dialysis or ESRD patients on heamodialysis more than 6 months. Chronic HCV infection with Plasma HCV RNA greater than $10,000 \mathrm{IU} / \mathrm{mL}$. Treatment naïve (no previous antiviral therapy). Compensated liver cirrhosis. Absence of coinfection with $\mathrm{HBV}$ or HIV.

Exclusion criteria: Patients with $\mathrm{HBV}+\mathrm{ve}$ or HIV. Prior antiviral therapy. Hb less than $10 \mathrm{mg} / \mathrm{dl}$. Decompensated liver disease. ESRD patints on heamodialysis less than 6 months.

Methodology: All the patients included in this study will be subjected to the following investigation: Full history taking and clinical examination. Laboratory investigations including: Hepatitis markers (HBsAg, HCV Ab) and HIV-Abs. by ELIZA, PCR for HCV RNA before starting treatment and 6 months after the end of the therapy. Liver function tests.

Prothrombin time and concentration. Compelete blood count. Blood Urea and serum creatinine. Estimated GFR: Which was calculated by MDRD. $\mathrm{eGFR}=175 \times($ S.cr) $-1.154 \times$ (age) $-0.203 \times 0.742$ (if female) x 1.212 (if black) $\mathrm{ml} / \mathrm{min} / 1.73 \mathrm{~m}^{2}$ Staging of CKD according to KDIGO guidelines 2016.

Radiological examination by Abdominal Ultrasound.

Statistical analysis: Data was collected and analyzed those using SPSS (Statistical Package for the Social Science, version 20, IBM, and Armonk, New York). Continuous data was expressed in form of mean \pm SD or median (range) while nominal data was expressed in form of frequency (percentage). $\mathrm{Chi}^{2}$-test was used to compare the nominal data of both groups in the study while student $t$-test was used to compare mean of both groups while pre- and post-therapy liver enzymes ad hemoglobin level in each group was compared by Paired $t$-test.

\section{Results}

Table (1): Demographic data of studied patients.

\begin{tabular}{|c|c|c|c|}
\hline Variables & $\begin{array}{c}\text { Group I } \\
(\mathrm{n}=20)\end{array}$ & $\begin{array}{c}\text { Group II } \\
(\mathrm{n}=20)\end{array}$ & $\begin{array}{c}p- \\
\text { value }\end{array}$ \\
\hline Age (years) & $42.1 \pm 15.01$ & $47.1 \pm 8.73$ & 0.21 \\
\hline Range & $18-70$ & $34-60$ & \\
\hline \multicolumn{4}{|l|}{ Sex: } \\
\hline Male & $12(60 \%)$ & $10(50 \%)$ & \multirow[t]{2}{*}{0.09} \\
\hline Female & $8(40 \%)$ & $10(50 \%)$ & \\
\hline \multicolumn{4}{|l|}{ Occupation: } \\
\hline No job & $7(35 \%)$ & $12(60 \%)$ & \multirow[t]{7}{*}{0.06} \\
\hline Housewife & $6(30 \%)$ & $2(10 \%)$ & \\
\hline Engineer & $2(10 \%)$ & $2(10 \%)$ & \\
\hline Employee & $4(20 \%)$ & 0 & \\
\hline Student & 0 & $2(10 \%)$ & \\
\hline Doctor & $1(5 \%)$ & 0 & \\
\hline Other & 0 & $2(10 \%)$ & \\
\hline \multicolumn{4}{|c|}{ Comorbidities: } \\
\hline DM & $1(5 \%)$ & 0 & \multirow[t]{3}{*}{0.50} \\
\hline HTN & $10(50 \%)$ & $8(40 \%)$ & \\
\hline IHD & $2(10 \%)$ & $6(30 \%)$ & \\
\hline $\begin{array}{l}\mathrm{N} \text { : Number. } \\
\text { DM: Diabetes } \mathrm{n} \\
\text { - Group I inclu } \\
\text { with CKD. }\end{array}$ & 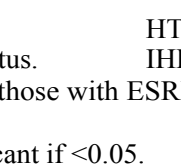 & $\begin{array}{l}\text { ypertension. } \\
\text { chaemic heart } \\
\text { ile group II ir }\end{array}$ & $\begin{array}{l}\text { ise. } \\
\text { ed those }\end{array}$ \\
\hline
\end{tabular}

Table (1) shows the demographic data of the studied patient. Mean age of patients with ESRD was $42.1 \pm 15.01$ years with range between 18-70 years while in patients with CKD; mean age was $47.1 \pm 8.73$ years with range between $34-60$ years.

Males represented $60 \%$ in case of ESRD and $50 \%$ in case of those with CKD. $12(60 \%)$ ad 7 (35\%) patients in those with CKD and ESRD were unemployed. Other occupations were explained at Table (10). $10(50 \%), 2(10 \%)$ and $1(5 \%)$ patients had HTN, IHD and DM respectively in those with ESRD while in case of CKD, $8(40 \%)$ patients had HTN and $6(30 \%)$ patients had IHD and non was diabetic.

As regarding the demographic data of both groups, there were no significant differences in between both groups with $p>0.05$. 
Table (2): Virological Response in both Studied Groups.

Table (2): Sustained virological response in the studied patients.

\begin{tabular}{lccc}
\hline Variables & Group I (n=20) & Group II (n=20) & $p$-value \\
\hline SVR at 12 weeks & $20(100 \%)$ & $20(100 \%)$ & 0.88 \\
SVR at 24 weeks & $17(85 \%)$ & $20(100 \%)$ & $0.01 *$ \\
\hline
\end{tabular}

N: Number.

= Group I included those with ESRD while group II included those with CKD.

$p$-value was significant if $<0.05$.

Sustained virological response (SVR) was assessed at 12 and 24 weeks post-therapy. All patients in each group achieved SVR at 12 weeks but three patients with ESRD failed to achieve SVR at 24 weeks. Therefore, finally $85 \%$ of patients with ESRD achieved SVR while all those with CKD achieved SVRwith significant difference $(p=0.01)$.

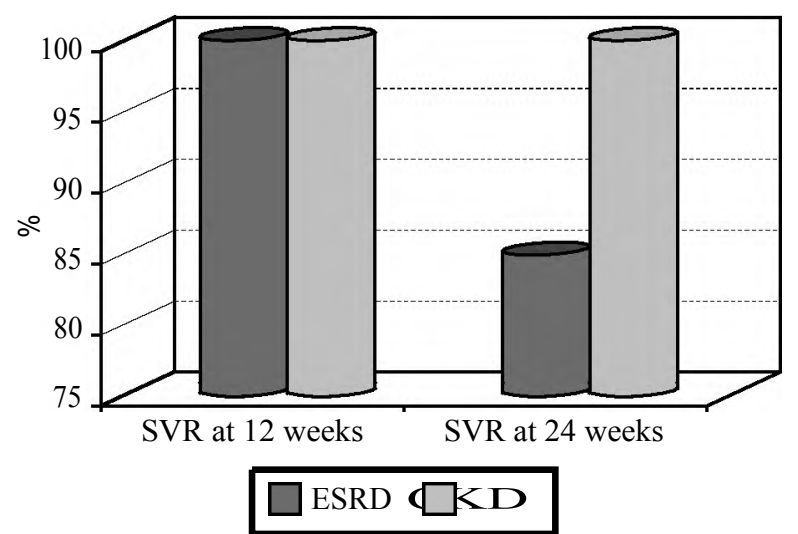

Fig. (1): Sustained virological response in both studied groups $(p=0.01)$.

\section{Adverse effects during course of therapy:}

Adverse effects occurred during therapy are summarized at Table (3). The most frequent adverse effect was irritability that was noticed in $10(50 \%)$ patients with ESRD and five patients $(25 \%)$ with CKD $(p=0.00) .8(40 \%)$ and $6(30 \%)$ patients with ESRD and CKR suffered from fatigue during course of therapy $(p=0.99)$.

Table (3): Adverse effects during course of therapy.

\begin{tabular}{llll}
\hline Variables & $\begin{array}{c}\text { Group I } \\
(\mathrm{n}=20)\end{array}$ & $\begin{array}{c}\text { Group II } \\
(\mathrm{n}=20)\end{array}$ & $p$-value \\
\hline Irritability & $10(50 \%)$ & $5(25 \%)$ & 0.00 \\
Nasopharyngitis & $2(10 \%)$ & $2(10 \%)$ & 0.09 \\
Pruritus & $6(30 \%)$ & $4(20 \%)$ & 0.66 \\
Insomnia & $3(15 \%)$ & $4(20 \%)$ & 0.11 \\
Nausea and vomiting & $2(10 \%)$ & 0 & 0.06 \\
Fatigue & $8(40 \%)$ & $6(30 \%)$ & 0.99 \\
Diarrhea & $1(5 \%)$ & $1(5 \%)$ & 0.43 \\
\hline N: Number. & \multicolumn{3}{l}{} \\
- Group I included those with ESRD while group II included those \\
\multicolumn{2}{l}{ with CKD. $p$-value was significant if $<0.05$}
\end{tabular}

\section{Discussion}

In our study, the Sustained virological response (SVR) was assessed at 12 and 24 weeks posttherapy. All patients in each group achieved SVR at 12 weeks but three patients with ESRD failed to achieve SVR at 24 weeks. Therefore, finally $85 \%$ of patients with ESRD achieved SVR while all those with CKD achieved SVR by $100 \%$.

This in agreement with Muñoz-Gómez study [6] which demonstrated that SVR 12 week was $100 \%$ per protocol, across all regimens and viral genotypes, and was independent of renal impairment or haemodialysis. But SVR 24 weeks, our study disagrees with them as they found that Data from week 24 post-treatment were available from 38 patients, in all of them viral load remained undetectable. A possible explanation for such discrepancy among reported studies is differences in the genotypes and our patients are non-compliant for treatment.

In agreement with our study, another study by Sanai [12], a 12-week regimen of OBV/PTV/r \pm DSV with or without RBV was highly effectiveas SVR was $100 \%$ with a favorable safety profile amongst HCV GT1 and GT4 patients on hemodialysis.

In concordance with our study: ABACUS [8] study stated that SVR at 12 week was $100 \%$ with the regimen of ombitasvir, paritaprevir, and ritonavir, with or without dasabuvir, plus ribavirin for patients with hepatitis C virus genotype 1 or 4 infection with cirrhosis (Petta et al., 2017).

In concordance with us, Atsukawaet [3] found that all patients completed the 12-week treatment course andachieved SVR12.

In addition, Ponziani [11] stated clinical and virologic assessment was performed every 4 weeks during the treatment and at post treatment weeks 4 and 12. All patients achieved a sustained virologic response at post treatment week 12 .

Pockros [10] has evaluated that plasma HCV RNA was suppressed less than the lower limit of quantification (LLOQ) (75\%) patients by week 2 , and in $(95 \%)$ Patients by treatment week 4 . All 20 patients completed 12 weeks of treatment and all were virologically suppressed at the end of treatment. Nevertheless, the intent-to-treat SVR12 rate was $90 \%$ as the patients who failed to achieve SVR 12 have low adherent for the regimen.

In agreement with Hézode [4] study done between Aug. 14, 2012, and Nov. 19, 2013, SVR12 
rates were $100 \%$ in the ribavirin-containing regimen.

But at SVR 24 we disagree with them as they experienced no relapses between post treatment week 12 and post treatment week 24 have been recorded in treatment-naive patients, a possible explanation that the difference of the genotypes of $\mathrm{HCV}$.

Agreed with RUBY-I study [9] stated that all patients to have achieved end of treatment (EOT) response. All 13 patients with available data at post-treatment week 4 and all 6 patients with available data at post-treatment week 12 achieved SVR. There are no virologic failures to date.

Abad [1] had a study on thirty-five patients aged $53.3 \pm 8.9$ years $(68.6 \%$ males) and with genotypes, 1 and 4 were treated with the regimen, and 17 were given ribavirin. They revealed that sustained viral response was achieved in 100\% of patients. Adverse effects were negligible, and no patient had to discontinue treatment. The most significant side effect was anemia, which led to a significant increase in the dose of erythropoiesis-stimulating agents. Anemia was more marked in patients receiving ribavirin. No patients required transfusions. The most frequent adverse effects in our study were irritability that was noticed in $(50 \%)$ patients with ESRD and (25\%) with CKD. (40\%) and (30\%) patients with ESRD and CKD suffered from fatigue during course of therapy. Nasopharyngitis in ERSD patients was (10\%) and in CKD patients was (10\%). Pruritus in ESRD patients was (30\%) and in ESRD patients was (20\%). Insomnia in ESRD patients was $(15 \%)$ and in CKD patients was (20\%). Nausea and vomiting in ESRD patients were (10\%) and in CKD, patients were 0. Fatigue in ESRD patients (40\%) and in CKD patients (30\%). Diarrhea in ESRD patients was (5\%) and CKD patients was $(5 \%)$. They were controlled on supportive therapy and all patients continued the course of therapy.

In Muñoz-Gómez [6] study, half of all patients experienced minor AEs related to the treatment. Asthenia, pruritus and gastrointestinal disorders were frequent. None of the serious AEs reported was medication related.

In contrast to our study, ABACUS study [8] found that (3\%) patients discontinued treatment because of adverse events. Asthenia was the most commonly reported adverse event, occurring in $(5 \%)$ patients.

Also Atsukawaet [3] found that the TEAEs were pruritus in two patients, peripheral edema in one, headache in one, fatigue in one. erythema multiforme in one, gastrointestinal bleeding in one, insomnia in one, numbness in one, and abdominal distension in one. In contrast to us

Erythema multiforme was observed in one patient. This patient only discontinued treatment at 5 weeks and recovere quickly.

Ponziani [11] demonstrated that $80 \%$ of patients reported at least one adverse event: Fatigue of mild intensity were the most common.

Pockros [10] revealed that Most patients experienced AEs, the majority of which were mild or moderate in severity No patient discontinued DAAs due to AE. The most common AEs were anemia $(45 \%)$, fatigue $(35 \%)$, diarrhea $(25 \%)$, and nausea $(25 \%)$. Nine treatment-emergent serious AEs were reported in 4 patients, although none were attributed to DAAs or RBV.

Also, Hézode [4] demonstrated that the most common treatment-emergent adverse events were headache $(33 \%)$, asthenia (33\%) fatigue $(18 \%)$, insomnia (16\%), and nausea (17\%). No patients had treatment-emergent adverse event-related dis continuations or dose interruptions.

In conclusion: The curability of Ombitasvir/ Paritaprevir/Ritonavir plus Ribavirin has SVR 12 about $100 \%$ and SVR24 100\% in CKD patients, $85 \%$ in ESRD patients.

With less incidence of anemia with that regimen as only $10 \%$ patients need blood transfusion.

With high tolerability and less side effects with no occurrence of discontinuation of treatment.

\section{Conflicts of interest:}

The Authors declare that there is no conflict of interest.

Funding:

The Authors certify that no funding has been received for the conduct of this study.

\section{References}

1- ABAD S., VEGA A., HERNÁNDEZ E., MÉRIDA E., DE SEQUERA P., ALBALATE M., MACÍAS N., MILLA M. and LÓPEZ-GÓMEZ J.M.: Universal Sustained Viral Response to the Combination of Ombitasvir/Paritaprevir/ Ritonavir and Dasabuvir with/without Ribavirin in Patients on Hemodialysis Infected with Hepatitis C Virus Genotypes 1 and 4. American Journal of Nephrology, 45: 267272, 2017.

2- AbbVie Inc. Technivie: (Ombitasvir, paritaprevir and ritonavir tablets, for oral use: US prescribing information. http:/www. technivie. com/. Accessed 24 Jun 2016), 2016. 
3- ATSUKAWA M., TSUBOTA A., KOUSHIMA Y., IKEGAMI T., WATANABE K., SHIMADA N., SATO S., KATO K., ABE H., OKUBO T., ARAI T., ITOKAWA N., KONDO C., MIKAMI S., ASANO T., CHUGANJI Y., MATSUZAKI Y. and IWAKIRI K.: Efficacy and safety of ombitasvir/paritaprevir/ritonavir in dialysis patients with genotype $1 \mathrm{~b}$ chronic hepatitis $\mathrm{C}$. Hepatology Research, 47 (13): 1429-1437, 2017.

4- HÉZODE C., ASSELAH T., REDDY K.R., HASSANEIN T., BERENGUER M., FLEISCHER-STEPNIEWSKA K., MARCELLIN P., HALL C., SCHNELL G., PILOTMATIAS T., MOBASHERY N., REDMAN R., VILCHEZ R.A. and PROF POL S.: Ombitasvir plus paritaprevir plus ritonavir with or without ribavirin in treatment-naive and treatment-experienced patients with genotype 4 chronic hepatitis $\mathrm{C}$ virus infection (PEARL-I): A randomised, open-label trial. The Lancet, 385 (9986): 2502-2509, 2015.

5- LIU Z., TIAN Y., MACHIDA K., LAI M.M., LUO G., FOUNG S.K. and OU J.H.: Transient activation of the PI3 K-AKT pathway by hepatitis C virus to enhance viral entry. The Journal of Biological Chemistry, 287 (50): 41922-41930, 2012.

6- MUÑOZ-GÓMEZ R., RINCÓN D., AHUMADA A., HERNÁNDEZ E., DEVESA MJMUÑ̃Z, IZQUIERDO S., ORTIZ M., HERNÁNDEZ-ALBUJAR A., FERNÁNDEZ-RODRÍGUEZ C., CALVO M., GONZÁLEZ R. LOZANO M., CASTELLANO G. and FERNÁNDEZVÁZQUEZ I.: Therapy with ombitasvir/paritaprevir/ ritonavir plus dasabuvir is effective and safe for the treatment of genotypes 1 and 4 hepatitis $\mathrm{C}$ virus (HCV) infection in patients with severe renal impairment: A multicentre experience. Journal of Viral Hepatits, 24: 464-471, 2017.

7- PAPATHEODORIDIS G. and HATZAKIS A.: Public health issues of hepatitis $\mathrm{C}$ virus infection. Best Practice \& Research Clinical Gastroenterology, 26 (4): 371-380, 2012.

8- PETTA S., MARZIONI M., RUSSO P., AGHEMO A., ALBERTI A., ASCIONE A., ANTINORI A., BRUNO R.,
BRUNO S., CHIRIANNI A., GAETA G.B., GIANNINI E.G., MERLI M., MESSINA V., MONTILLA S., PERNO C.F., PUOTI M., RAIMONDO G., RENDINA M., SILBERSTEIN F.C., VILLA E., ZIGNEGO A.L., PANI L. and CRAXİ A.: Ombitasvir, paritaprevir, and ritonavir, with or without dasabuvir, plus ribavirin for patients with hepatitis $C$ virus genotype 1 or 4 infection with cirrhosis (ABACUS): A prospective observational study. The Lancet Gastroenterology \& Hepatology, 2 (6): 427-34, 2017.

9- POCKROS P., REDDY K., MANTRY P., COHEN E., BENNETT M., SULKOWSKI M.S., BERNSTEIN D., PODSADECKI T., COHEN D., SHULMAN N., WANG D., KHATRI A., ABUNIMEH M., LAWITZ E. and RUBY-I: Ombitasvir/paritaprevir/ritonavir+ dasabuvir $\pm_{\text {riba- }}$ virin in non-cirrhotic HCV genotype1-infected patients with severe renal impairment or end-stage renal disease. Gastroenterology, 15: 1590-1598, 2015.

10- POCKROS P.J., REDDY K.R., MANTRY P.S., COHEN E., BENNETT M., SULKOWSKI M.S., BERNSTEIN D.E., COHEN D.E., SHULMAN N.S., WANG D., KHATRI A., ABUNIMEH M., PODSADECKI T. and LAWITZ E.: Efficacy of direct-acting antiviral combination for patients with hepatitis $C$ virus genotype 1 infection and severe renal impairment or end-stage renal disease. Gastroenterology, 150 (7): 1590-1598, 2016.

11- PONZIANI F.R., SICILIANO M., LIONETTI R., PAS QUAZZI C., GIANSERRA L., D'OFFIZI G., GASBARRINI A. and POMPILI M.: Effectiveness of Paritaprevir/ Rito-navir/Ombitasvir/Dasabuvir in Hemodialysis Patients With Hepatitis C Virus Infection and Advanced Liver Fibrosis. American Journal of Kidney Diseases, 70 (2): 297-300, 2017.

12- SANAI F.M., ALGHAMDI A.S., AFGHANI A., ALSWAT K.A., ASEERI M., ASSIRI A.M. and BABATIN M.A.: $100 \%$ efficacy to ombitasvir/paritaprevir/ritonavir ( \pm dasabuvir) with or without ribavirin in hepatitis $\mathrm{C}$ virus genotypes 1 and 4-infected hemodialysis patients. Journal of Hepatology, 66 (1): S312, 2017.

13- SARHAN I.I. and KAMEL C.R.: Prevalence of hepatitis $C$ virus seroconversion among hemodialysis patients in Egypt. Egyptian Liver Journal, 5 (2): 34-9, 2015. 


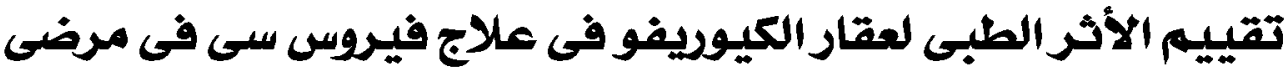

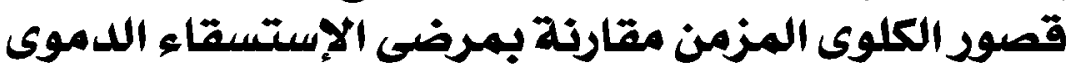

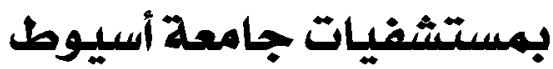

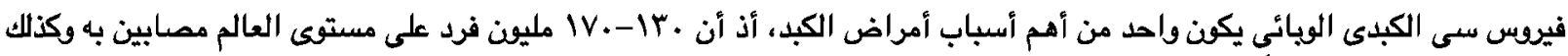

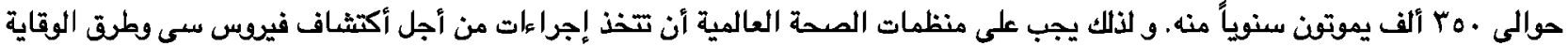
والعلاج منه.

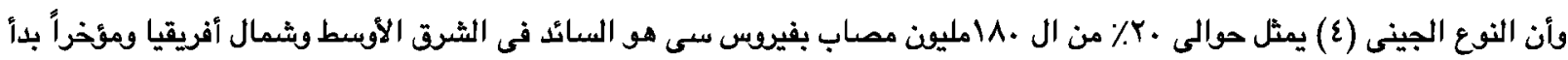

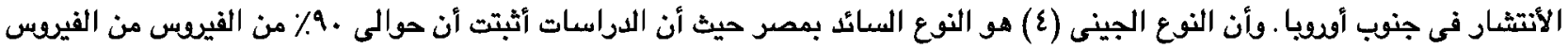

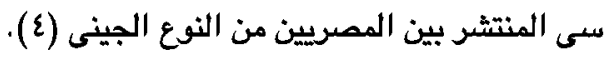

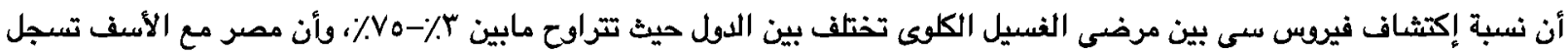
أعلى معدلات من الإصابة به على الرغم من تطبيق برامج مكافحة العدوىى.

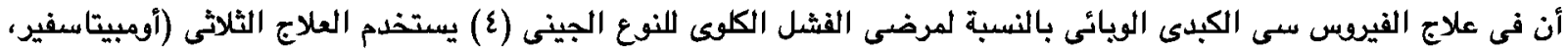

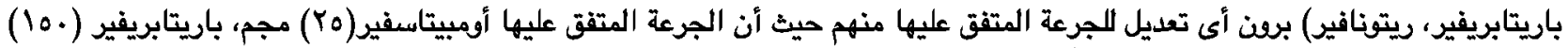

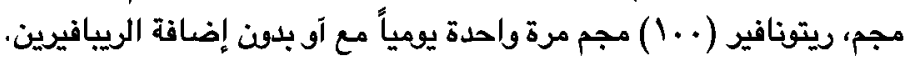

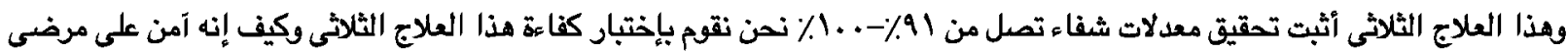
الفشل الكلوى.

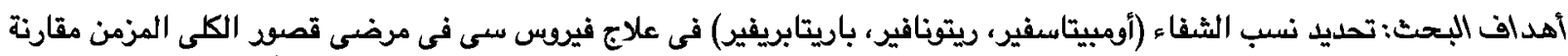

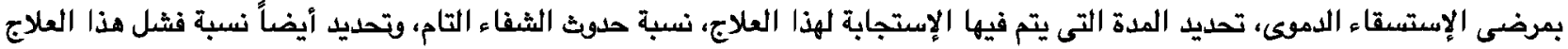
بين هؤلاء المرضى.

معايير الأستبعاد : تم أستبعاد الذين يعانون من فيروس بى الكبدى أو الإيدز، من تعرضوا لعلاج فيروس سى من قبل، أو من لديهم نسبة

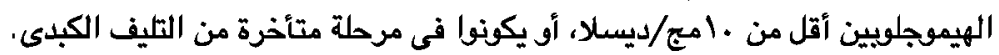

طرق العلاج: الدراسة أشتملت على •ع مريض فى جامعة أسيوط تم تقسيمه إلى مجموعتين:

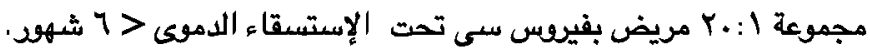

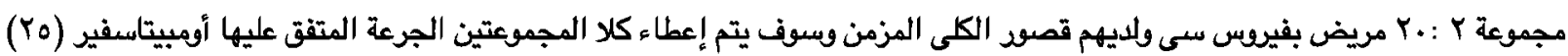

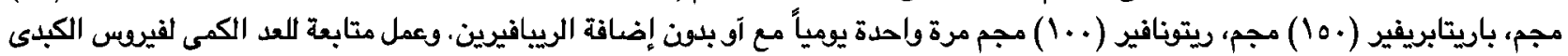
قبل بدء العلاج وبعد أنتهاء العلاج ب 7 أشهر.

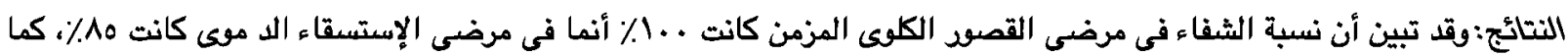

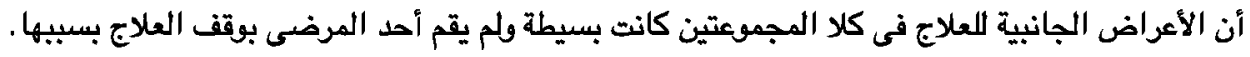

